Vol. 1 No. 3 November 2021 e-ISSN : 2797-1031 | p-ISSN : 2797-0744

\title{
PENERAPAN MODEL KEMANDIRIAN AKTIF SECARA DARING UNTUK MENINGKATKAN AKTIVITAS DAN PENGUASAAN MATERI FENOMENA KUANTUM SISWA SMA NEGERI 2 BANDAR LAMPUNG TAHUN PELAJARAN 2020/2021
}

\author{
ATO SUHARTO \\ SMA Negeri 2 Bandar Lampung - Provinsi Lampung \\ e-mail: ato.sman2bdl@gmail.com
}

\begin{abstract}
ABSTRAK
Kurangnya gairah dalam belajar Fisika pada era Pandemi Covid-19 ini, mengakibatkan hasil belajar Fisika yang kurang optimal, hal ini yang menggerakan penulis untuk melakukan penelitian dengan tujuan; (1). Mendeskripsikan aktivitas siswa dalam kegiatan pembelajaran menggunakan model kemandirian aktif, (2). Mendeskripsikan penguasaan siswa terhadap materi fenomena kuantum menggunakan model kemandirian aktif. Percontoh dalam penelitian ini, yakni kelas XII MIPA-6 yang mempunyai karakteristik; penguasaan materi fenomena kuantum siswa rendah, dan aktivitas siswa terbatas pada duduk, mencatat, dan mendengarkan. Pengambilan data pada penelitian ini dilakukan menggunakan; (1). Lembar observasi siswa, (2). Lembar observasi guru, (3). Lembar kerja kelompok dan lembar review presentasi yang dilakukan pada setiap pertemuan, (4) Lembar tugas mandiri yang dilakukan pada setiap siklusnya, dan (5) Tes evaluasi yang dilaksanakan pada setiap akhir siklus. Data yang dianalisis pada penelitian ini terdiri dari; (1). Data Kualitatif, merupakan data hasil observasi yang terdiri dari data aktivitas siswa dan data aktivitas guru peneliti, (2). Data Kuantitatif, berupa nilai yang diambil dari kerja ilmiah kelomok, nilai review presentasi, nilai tugas mandiri dan nilai evaluasi akhir siklus. Berdasarkan hasil penelitian diperoleh; (1). Peningkatan aktivitas siswa pada siklus I sebesar $80,56 \%$ meningkat menjadi $86,11 \%$ pada siklus II dan meningkat lagi menjadi $91,67 \%$ pada siklus III, (2). Peningkatan penguasaan materi fenomena kuantum siswa pada siklus I sebesar 50,85 menjadi 68,96 pada siklus II atau naik $18,11 \%$ dan meningkat pada siklus III menjadi 80,84 atau mengalami kenaikan sebesar $11,88 \%$.
\end{abstract}

Kata kunci: Hasil belajar, Fenomena kuantum, Kemandirian aktif, Daring, Pademi Covid-19.

\section{ABSTRACT}

Lack of passion in studying Physics in this Covid-19 Pandemic era, resulted in less than optimal Physics learning outcomes, this is what moves the author to conduct research with the aim of; (1). Describing student activities in learning activities using an active independence model, (2). Describing students' mastery of quantum phenomena using an active independence model. The sample in this study, namely class XII MIPA-6 which has the characteristics; students' mastery of quantum phenomena is low, and students' activities are limited to sitting, taking notes, and listening. Data collection in this study was carried out using; (1). Student observation sheet, (2). Teacher observation sheet, (3). Group work sheets and presentation review sheets were carried out at each meeting, (4) independent task sheets were carried out in each cycle, and (5) evaluation tests were carried out at the end of each cycle. The data analyzed in this study consisted of; (1). Qualitative data, is data from observations consisting of student activity data and research teacher activity data, (2). Quantitative data, in the form of values taken from the group's scientific work, presentation review scores, independent assignment scores and end-ofcycle evaluation scores. Based on the research results obtained; (1). The increase in student activity in the first cycle of $80.56 \%$ increased to $86.11 \%$ in the second cycle and increased again to $91.67 \%$ in the third cycle, (2). The increase in students' mastery of quantum phenomena in the first cycle was 50.85 to 68.96 in the second cycle or $18.11 \%$ and increased in the third cycle to 80.84 or an increase of $11.88 \%$.

Keywords: Learning outcomes, Quantum phenomena, Active independence, Online, Covid-19 pandemic. 


\section{Vol. 1 No. 3 November 2021 e-ISSN : 2797-1031 | p-ISSN : 2797-0744}

\section{PENDAHULUAN}

Penguasaan materi fenomena kuantum bagi siswa XII MIPA sangat penting. Apabila siswa telah menguasai materi fisika yang dipelajari sebelumnya maka akan lebih mudah menguasai materi fisika selanjutnya. Tetapi kenyataannya banyak siswa yang memiliki kemampuan penguasaan rendah terhadap materi fisika pada bab sebelumnya. Penguasaan materi yang rendah dipengaruhi oleh beberapa faktor, salah satunya karena siswa tidak terlibat aktif dalam kegiatan pembelajaran. Ketidakaktifan siswa ini disebabkan oleh penerapan strategi pembelajaran yang kurang tepat. Penguasaan materi yang rendah menyebabkan hasil belajar siswa menjadi rendah (Roestiyah, 1986). Berdasarkan observasi yang dilakukan pada SMA Negeri 2 Bandar Lampung diketahui bahwa kelas XII MIPA-6 memiliki penguasaan materi yang rendah dibandingkan dengan kelas XII MIPA yang lain. Hal ini dikarenakan siswa di kelas tersebut pasif. Hal ini berdasarkan pengalaman penulis saat mengajar fisika di SMA Negeri 2 Bandar Lampung, yang telah berupaya untuk menjelaskan materi dengan semaksimal mungkin dan dengan cara yang sama dengan kelas yang lain, namun ketika dilaksanakan penilaian harian ternyata sekitar $70 \%$ siswa di kelas tersebut mendapatkan nilai di bawah 7,0. nilai ini masih jauh dari standar kurikulum tahun 2017 yaitu belajar tuntas secara klasikal apabila siswa yang mendapat nilai $>7,0$ adalah $85 \%$, sedangkan ketuntasan secara klasikalnya dari data di tersebut adalah hanya $30 \%$.

Selain penguasaan terhadap materi yang masih rendah ternyata minat atau respon siswa untuk mempelajari fisika juga masih rendah, hal ini terlihat dari aktivitas siswa di kelas seperti tidak memperhatikan saat guru menerangkan, enggan mencatat, sering keluar masuk kelas, tampak bosan dalam belajar, serta terkesan sepenuhnya tergantung pada guru. Guru juga ikut berperan dalam terjadinya hal ini karena ketika siswa diberi kesempatan bertanya dan siswa tidak bertanya, guru lalu melanjutkan ke materi berikutnya tanpa memancing siswa dengan pertanyaan yang harus dijawab. Kurangnya usaha guru dalam memvariasikan metode pembelajaran mengakibatkan siswa hanya duduk, diam, dengar, catat dan tidak terlibat secara aktif dalam proses pembelajaran.

Permasalahan di atas harus ditanggulangi, sehingga perlu dilakukan suatu penelitian yang bersifat reflektif, yaitu melakukan tindakan-tindakan tertentu yang direncanakan. Tindakan-tindakan yang akan dilakukan dalam proses pembelajaran diharapkan dapat mengubah suasana pembelajaran siswa yang pasif kearah pembelajaran yang memungkinkan siswa untuk bersifat lebih aktif (Roestiyah, 1988). Belajar mandiri akan membuat siswa menjadi lebih aktif, karena dalam belajar mandiri siswa diharuskan menyelesaikan tugas atau masalah yang ada melalui analisis, sintesis dan evaluasi (Djamin, 1997).

Tindakan yang telah dilakukan oleh peneliti untuk menyelesaikan masalah-masalah di atas adalah melakukan pembelajaran dengan model kemandirian aktif. model kemandirian aktif merupakan sebuah model yang dirancang berdasarkan system belajar mandiri dan belajar aktif. Dengan model ini diharapkan akan dapat mengembangkan pola berpikir siswa menjadi lebih aktif dalam; (1). Mempelajari gagasan-gagasan, (2). Memecahkan berbagai masalah, (3). Menerapkan apa yang mereka pelajari, (4). Menguasai materi yang mencakup pengetahuan, (5). Menguasai matei yang mencakup pemahaman, dan (6). Menguasai matei yang mencakup kemampuan mengaplikasi suatu materi fisika yang dimiliki siswa.

Berdasarkan permasalahan yang telah diungkapkan, secara umum penelitian ini bertujuan untuk meningkatkan pemahaman siswa, sedangkan secara terperinci tujuan penelitian ini adalah; (1). Mendeskripsikan aktivitas siswa dalam kegiatan pembelajaran menggunakan model kemandirian aktif, (2). Mendeskripsikan penguasaan siswa terhadap materi fenomena kuantum mengunakan model kemandirian aktif.

Hasil penelitian ini diharapkan dapat memberikan beberapa manfaat yang berguna antara lain sebagai berikut; Bagi guru, (1). Sebagai informasi dalam menentukan alternative strategi pembelajaran sehingga dapat memecahkan masalah yang dihadapi siswa, (2). Menambah wawasan sehingga dapat mengembangkan pembelajaran fisika dengan menerapkan model kemandirian aktif pada kelas XII MIPA-6 sebagai upaya untuk meningkatkan 


\section{Vol. 1 No. 3 November 2021 e-ISSN : 2797-1031 | p-ISSN : 2797-0744}

penguasaan materi dan aktivitas belajar siswa. Bagi siswa, menumbuhkan motivasi dan minat belajar fisika karena mereka terlibat secara aktif dalam proses pembelajaran.

Agar penelitian yang dilakukan tidak salah ditafsirkan dan menyimpang dari tujuan, peneliti membatasi penelitian yang dilakukan yaitu; (1). Subjek penelitian ini adalah siswa kelas XII MIPA-6 semester genap SMA Negeri 2 Bandar Lampung tahun pelajaran 2020/2021, (2). Materi pembelajaran dalam penelitian ini adalah fenomena kuantum, (3). Pembelajaran dengan model kemandirian aktif dimaksudkan untuk meningkatkan aktivitas dan hasil belajar siswa, karena dalam pembelajaran ini dikembangkan bentuk kegiatan belajar kelompok dan belajar perorangan. Kegiatan belajar kelompok dilakukan dengan tujuan membina kerja sama antar siswa, sedangkan kegiatan belajr prorangan merupakan wahana untuk mengembangkan kemandirian dan potensi yang optimal dalam diri masing-masing siswa. Disamping itu kegiatan belajar klasikal tetap dipakai dengan tujuan guru dapat memberi penjelasan dan memperlihatkan materi secara jelas. Langkah-langkah dalam pembelajaran menggunakan model kemandirian aktif adalah; (a). Menyampaikan materi, (b). Memberi contoh, (c). Memberi penugasan, (d). Mengevaluasi proses, (e). Memberi tugas mandiri, (f). Mengevaluasi hasil. (4). Aktivitas siswa adalah kegiatan siswa yang ada dalam proses pembelajaran meliputi aspek perilaku siswa yang tidak relevan dengan kegiatan pembelajaran yaitu berbicara di luar pelajaran, memandang ke kanan dan ke kiri, mengerjakan tugas lain, mengganggu teman dan tidak mendengarkan atau memperhatikan penjelasan guru, (5). Penguasaan materi fisika yang dimaksudkan adalah dilihat dari kemampuan siswa untuk melakukan kerja ilmiah, mereview presentasi, mengerjakan tugas mandiri dan mengerjakan soal-soal evaluasi yang diberikan pada setiap akhir siklus.

\section{METODE PENELITIAN}

Subjek penelitian ini adalah kelas XII MIPA-6 SMA Negeri 2 Bandar Lampung. Dalam pembelajaran ini siswa dikelompokan menjadi delapan kelompok dengan masing-masing kelompok terdiri dari 4 atau 5 orang siswa yang dipilih secara acak dari 36 siswa. Penelitian ini dilaksanakan di kelas XII MIPA-6 pada semester genap Tahun Pelajaran 2020/2021. Peneitian dilakukan di kelas XII MIPA-6 yang memiliki karakter khusus sebagai berikut; (1). Penguasaan materi fisika rendah, (2). Aktivitas siswa terbatas pada duduk, mencatat dan mendengarkan, (3). Guru mendominasi pelajaran. Metode yang digunakan dalam penelitian ini kemandirian aktif. Metode kemandirian aktif adalah metode pembelajaran yang memungkinkan siswa untuk aktif belajar secara mandiri dengan panduan dan arahan dari guru. Dalam metode kemandirian aktif siswa lebih banyak berperan untuk lebih aktif dalam belajar, sedangkan guru hanya sebagai fasilitator dalam pembelajaran. Metode semacam ini dipandang cocok digunakan untuk pembelajaran di masa pandemi Covid-19.

Dalam penelitian ini pembelajaran dilakukan secara on-line dan off-line secara bergantian berdasarkan nomor absen ganjil dan genap. Sedangkan platform yang digunakan dalam pembelajaran yang dilakukan secara on-line pada penelitian masa pandemi ini adalah Zoom Meeting, Google Class Room (GCR), WhatsApp (WA), e-mail, Google Form, Facebook, Youtube, beberapa link pembelajaran dan lain-lain. Sedangkan pertemuan yang dilakukan dengan cara Pertemuan Tatap Muka (PTM) Terbatas dengan menerapkan protokol kesehatan yang sangat ketat (Kemenkes, 2020).

Prosedur penelitian ini terdiri dari beberapa siklus belajar sesuai dengan kebutuhan di kelas. Setiap siklus dilaksanakan dengan perubahan yang ingin dicapai, seperti yang telah direncanakan dalam faktor yang akan diselidiki. Penelitian ini merupakan penelitian kelas dangan menggunakan prosedur; 1. Tahap Perencanaan; (a). Membuat silabus yang sesuai dengan pembelajaran dangan model kemandirian aktif, (b). Membuat rencana pembelajaran yang sesuai dengan langkah-langkah pembelajaran dengan model kemandirian aktif, (c). Membuat lembar observasi terfokus untuk melihat tindakan siswa selama pembelajaran dan membuat lembar pengamatan penguasaan siswa terhadap materi pelajaran, (d). Membuat lembar observasi terfokus untuk melihat tidakan guru peneliti selama pembelajaran, (e). 
Vol. 1 No. 3 November 2021 e-ISSN : 2797-1031 | p-ISSN : 2797-0744

\begin{tabular}{clc}
\hline 1 & Tugas Kelompok (10\%) & 66,67 \\
2 & Review Presentasi (10\%) & 69,11 \\
3 & Tugas Mandiri (20\%) & 65,82 \\
4 & $\begin{array}{l}\text { Evaluasi Akhir Siklus } \\
(60 \%)\end{array}$ & 40,18 \\
\hline \multicolumn{1}{c}{ Nilai Akhir } & 50,85 \\
\hline
\end{tabular}

Dari data di atas terlihat bahwa penguasaan fisika siswa pada pembelajaran menggunakan model kemandirian aktif masih kurang memuaskan, yaitu rata-rata hanya 50,85.

Berdasarkan hasil wawancara antara guru peneliti dengan guru mitra, diperoleh gambaran bahwa secara umum guru peneliti cukup mampu menerapkan pembelajaran model kemandirian aktif tetapi belum sempurna dalam pembelajaran di kelas. Pada proses pembelajaran dengan model kemandirian aktif, guru sudah dapat membimbing siswa untuk berdiskusi dalam kelompok dan terlibat aktif dalam kegiatan pembelajaran. Yang belum dilakukan dengan baik oleh guru peneliti adalah pengelolaan waktu proses pembelajaran. Rekomendasi perbaikan rencana tindakan siklus II adalah sebagai brikut; (1). Mempertahankan kinerja yang dilakukan oleh guru selama melakukan tindakan pembelajaran pada siklus I, (2). Mengatur pengelolaan waktu presentasi dengan lebih baik, (3). Memberi penjelasan yang lebih lengkap kepada siswa agar siswa lebih semangat belajar

Di kelas XII MIPA-6 pembelajaran fisika siklus II dilaksanakan selama satu kali pertemuan sesuai jadwal. Pertemuan kedua dilaksanakan pada hari Senin tanggal 18 Januari 2021. Pertemuan kedua digunakan untuk melakukan kegiatan pembelajaran berupa pemberian informasi, kerja ilmiah, presentasi dan tugas mandiri. Serta digunakan untuk memberi tes evaluasi akhir siklus kepada siswa. Pada pertemuan pertama ini dihadiri oleh 36 siswa. Materi yang dipelajari adalah fenomena kuantum pada sub konsep efek foto listrik.

Data hasil ketercapaian aktivitas siswa pada siklus II dapat dilihat pada tabel 4:

Tabel 4. Data Aktivitas Siswa pada Proses Pembelajaran Siklus II

\begin{tabular}{clr}
\hline \hline No & Aktivitas Siswa & Ketercapaian \\
\hline 1 & Sesuai dengan KBM (On-Task) & $86,11 \%$ \\
2 & Tidak Sesuai dengan KBM (Off-Task) & $13,89 \%$ \\
\hline \multicolumn{2}{c}{ Jumlah } & $100,00 \%$ \\
\hline
\end{tabular}

Hasil yang diperoleh bahwa aktivitas dalam pembelajaran menggunakan model kemandirian aktif cukup memuaskan (persentase aktivitas siswa lebih dari 86\%). Tapi amat disayangkan masih ada siswa yang kurang aktif. Kemungkinan hal ini disebabkan karena siswa tidak ada keinginan belajar.

Data hasil observasi aktivitas guru pada siklus II dapat dilihat pada tabel 5:

Tabel 5. Data Observasi Aktivitas Guru Pada Siklus-II

\begin{tabular}{clr}
\hline \hline No & Kriteria & Ketercapaian \\
\hline 1 & Sangat Baik & $30,56 \%$ \\
2 & Baik & $58,33 \%$ \\
3 & Cukup Baik & $11,11 \%$ \\
4 & Kurang Baik & $0 \%$ \\
\hline \multicolumn{2}{l}{ Jumlah } & $100,00 \%$ \\
\hline
\end{tabular}

Pada siklus II sebagian besar aktivitas guru baik. Faktor yang masih kurang adalah membimbing siswa untuk berdiskusi dalam kelompok masih kurang optimal.

Data penguasaan fisika siswa siklus II dapat dilihat pada tabel 6: 
Vol. 1 No. 3 November 2021 e-ISSN : 2797-1031 | p-ISSN : 2797-0744

Tabel 6. Data Penguasaan Materi Fisika Siswa Pada Siklus II

\begin{tabular}{clr}
\hline \hline No & Aspek yang Dinilai & Siklus II \\
\hline 1 & Tugas Kelompok (10\%) & 68,82 \\
2 & Review Presentasi (10\%) & 67,85 \\
3 & Tugas Mandiri (20\%) & 89,92 \\
4 & Evaluasi Akhir Siklus & 62,18 \\
\hline & $(60 \%)$ & 68,96 \\
\hline
\end{tabular}

Dari data di atas terlihat bahwa penguasaan fisika siswa pada pembelajaran menggunakan model kemandirian aktif cukup memuaskan yaitu rata-rata 68,96. Karena penguasaan fisika meningkat 18,11 dari siklus I.

Berdasarkan hasil wawancara antara guru peneliti dengan guru mitra, diperoleh gambaran bahwa secara umum guru peneliti cukup mampu menerapkan pembelajaran model kemandirian aktif tetapi belum sempurna dalam pembelajaran di kelas. Pada proses pembelajaran dengan model kemandirian aktif, guru sudah dapat membimbing siswa untuk berdiskusi dalam kelompok dan terlibat aktif dalam kegiatan pembelajaran namun kurang merata karena masih ada siswa yang kurang termotivasi untuk aktif. Guru peneliti telah melakukan pengelolaan waktu proses pembelajaran lebih baik dari siklus I. Rekomendasi perbaikan rencana tindakan siklus III; (1). Mempertahankan kinerja yang dilakukan oleh guru selama melakukan tindakan pembelajaran pada siklus II, (2). Lebih merata dalam memberikan perhatian kepada siswa dalam diskusi kelompok, (3). Memberi motivasi kepada siswa.

Di kelas XII MIPA-6 pembelajaran fisika siklus III dilaksanakan selama satu kali pertemuan sesuai jadwal. Pertemuan ketiga dilaksanakan pada hari Senin tanggal 25 Januari 2021. Pertemuan ketiga digunakan untuk melakukan kegiatan pembelajaran berupa pemberian informasi, kerja ilmiah, presentasi dan tugas mandiri. Serta digunakan untuk memberi tes evaluasi akhir siklus kepada siswa. Pada pertemuan ketiga ini dihadiri oleh 36 siswa. Materi yang dipelajari adalah fenomena kuantum dengan sub materi sinar X dan efek Compton.

Data hasil ketercapaian aktivitas siswa pada siklus III dapat dilihat pada tabel 7:

Tabel 7. Data Aktivitas Siswa pada Proses Pembelajaran Siklus III

\begin{tabular}{clr}
\hline \hline No & Aktivitas Siswa & Ketercapaian \\
\hline 1 & Sesuai dengan KBM (On-Task) & $91,67 \%$ \\
2 & Tidak Sesuai dengan KBM (Off-Task) & $8,33 \%$ \\
\hline Jumlah & $100,00 \%$ \\
\hline
\end{tabular}

Hasil yang diperoleh bahwa aktivitas dalam pembelajaran menggunakan model kemandirian aktif cukup memuaskan (persentase aktivitas siswa lebih dari 91\%). Hampir seluruh siswa mengikuti pembelajaran dengan baik.

Data hasil observasi aktivitas guru pada siklus III dapat dilihat pada tabel 8:

Tabel 8. Data Observasi Aktivitas Guru Pada Siklus-III

\begin{tabular}{clr}
\hline \hline No & Kriteria & Ketercapaian \\
\hline 1 & Sangat Baik & $69,44 \%$ \\
2 & Baik & $30,56 \%$ \\
3 & Cukup Baik & $0 \%$ \\
4 & Kurang Baik & $0 \%$ \\
\hline \multicolumn{2}{l}{ Jumlah } & $100,00 \%$ \\
\hline
\end{tabular}

Pada siklus III sebagian besar aktivitas guru semakin baik. Hal ini dikarenakan guru sudah dapat menggunakan model kemandirian aktif. 
Vol. 1 No. 3 November 2021 e-ISSN : 2797-1031 | p-ISSN : 2797-0744

Data penguasaan fisika siswa siklus III dapat dilihat pada tabel 9:

Tabel 9. Data Penguasaan Materi Fisika Siswa Pada Siklus III

\begin{tabular}{clr}
\hline \hline No & Aspek yang Dinilai & Siklus III \\
\hline 1 & Tugas Kelompok (10\%) & 74,58 \\
2 & Review Presentasi (10\%) & 82,41 \\
3 & Tugas Mandiri (20\%) & 89,82 \\
\multirow{2}{*}{4} & Evaluasi Akhir Siklus & 79,62 \\
\hline \multicolumn{2}{c}{$(60 \%)$} & 80,84 \\
\hline
\end{tabular}

Dari data di atas terlihat bahwa penguasaan fisika siswa pada pembelajaran menggunakan model kemandirian aktif cukup memuaskan yaitu rata-rata 80,84. Karena penguasaan fisika meningkat 12,48 dari siklus II. Berdasarkan hasil wawancara antara guru peneliti dengan guru mitra, diperoleh gambaran bahwa secara umum guru peneliti cukup mampu menerapkan pembelajaran model kemandirian aktif tetapi belum sempurna dalam pembelajaran di kelas. Pada proses pembelajaran dengan model kemandirian aktif, guru sudah dapat membimbing siswa untuk berdiskusi dalam kelompok dan terlibat aktif dalam kegiatan pembelajaran.

Jika kita mencoba membandingkan data-data aktivitas siswa pada proses pembelajaran mulai dari siklus I sampai dengan siklus III, maka diperoleh grafik sebagai berikut:

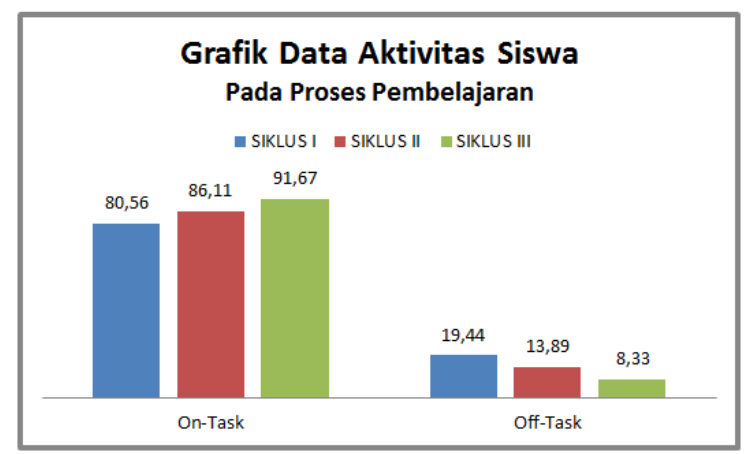

\section{Gambar 1. Grafik Data Aktivitas Siswa Pada Proses Pembelajaran}

Berdasarkan grafik tersebut dapat dilihat bahwa, aktivitas siswa pada proses pembelajaran mulai dari siklus I sampai dengan siklus III yang sesuai dengan proses Kegiatan Belajar Mengajar (On-Task) mengalami peningkatan jumlah, dari 80,56\% pada siklus I, 86,11\% pada siklus II, dan 91,67\% pada siklus III, atau mengalami kenaikan aktivitas 11,11\%. Hal ini dimungkinkan karena siswa tertarik dengan pembelajaran menggunakan model kemandirian aktif.

Selanjutnya jika kita mencoba membandingkan data-data observasi aktivitas guru pada proses pembelajaran mulai dari siklus I sampai dengan siklus III, maka diperoleh grafik sebagai berikut:

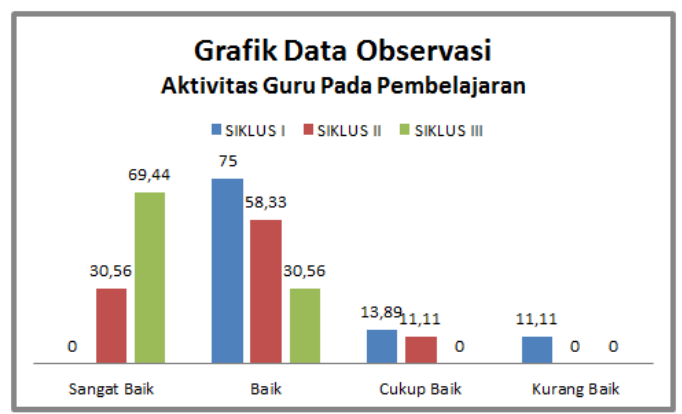

Gambar 2. Grafik Data Observasi Aktivitas Guru Pada Proses Pembelajaran 
Berdasarkan grafik tersebut dapat dilihat bahwa, observasi aktivitas guru pada proses pembelajaran mulai dari siklus I sampai dengan siklus III yang observasi aktivitasnya sangat baik mengalami peningkatan jumlah, dari $0 \%$ pada siklus I, 30,56\% pada siklus II, dan $69,44 \%$ pada siklus III, atau mengalami kenaikan obervasi aktivitas guru sebesar 69,44\%. Hal ini dimungkinkan karena guru mulai menemukan gaya belajar siswanya yaitu dengan pembelajaran menggunakan model kemandirian aktif (Saefullah: 2013).

Kemudian jika kita mencoba membandingkan data-data penguasaan materi fisika siswa dari proses pembelajaran mulai dari siklus I sampai dengan siklus III, maka diperoleh grafik sebagai berikut:

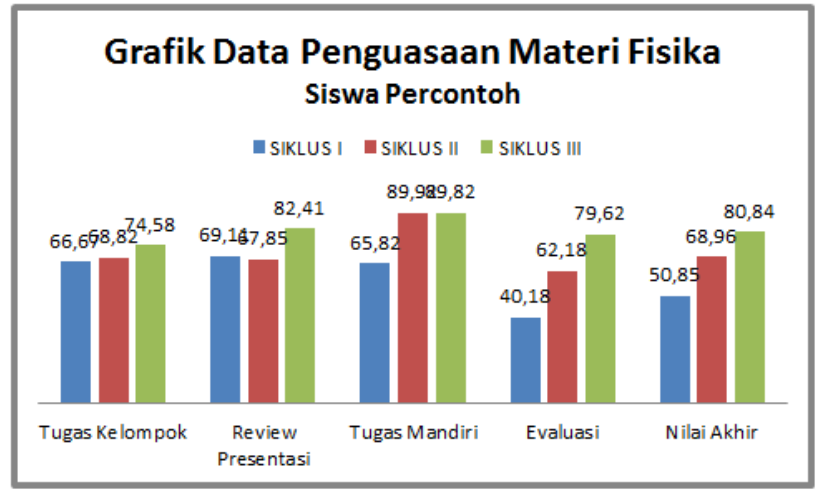

\section{Gambar 3. Grafik Data Penguasaan Materi Fisika Siswa dari Proses Pembelajaran}

Berdasarkan grafik tersebut dapat dilihat bahwa, nilai akhir siswa dari proses pembelajaran yang terdiri dari tugas kelompok, review presentasi, tugas mandirri, dan evluasi mulai dari siklus I sampai dengan siklus III mengalami peningkatan secara nyata, dari 50,85\% pada siklus I, 68,96\% pada siklus II, dan $80,84 \%$ pada siklus III, atau mengalami kenaikan penguasaan materi fisika siswa yang sangat nyata yaitu sebesar $29,99 \%$. Hal ini merupakan prestasi yang sangat baik dalam pembelajaran fisika, hal ini patut diduga karena siswa mulai menyukai pembelajaran menggunakan model kemandirian aktif. Hal senada terjadi pada tugas kelompok, mengalami kenaikan nilai walaupun tidak begitu nyata yaitu 7,91\%, review presentasi mengalami kenaikan sebesar $13,30 \%$, tugas mandiri mengalami kenaikan sebesar $24,00 \%$, dan evaluasi yang mengalami kenaikan sebesar 39,44\%.

Berdasarkan hasil dari siklus ke siklus diketahui bahwa aktivitas siswa, observasi guru dan hasil belajar atau penguasaan siswa terhadap materi fenomena kuantum menggunakan model pembelajaran aktif semakin meningkat. Materi fenomena kuantum berakhir tepat pada siklus III, sehingga siklus tindakan dihentikan.

\section{Pembahasan}

Pelaksanaan penelitian ini adalah pada masa pandemi covid-19. Pandemi berasal dari bahasa Yunani, "pan" yang artinya "semua" dan "demos" yang berarti "orang-orang" Pandemi ini biasa digunakan untuk merujuk pada epidemi yang luas penyakit menular di seluruh negara, satu atau lebih benua pada waktu yang bersamaan (Education, 2020). Menurut Kamus Besar Bahasa Indonesia (KBBI) pandemi berarti wabah penyakit yang terjangkit secara meluas dalam waktu yang serempak, (KBBI, 2020). Arti pandemi yang diterima secara internasional seperti yang muncul dalam Kamus Epidemiologi adalah langsung dan terkenal: "epidemi yang terjadi di seluruh dunia, atau di wilayah yang sangat luas, melintasi batas internasional dan biasanya mempengaruhi sejumlah besar orang" (Nadzhiroh, 2017). Berdasarkan arti dan definisi tersebut, pandemi dapat dikatakan sebagai sebuah keadaan di suatu negara atau beberapa negara yang secara bersamaan terjangkit wabah yang sama, bisa itu berupa virus ataupun penyakit lainnya yang berbahaya dan mematikan. Sedagkan yang dimaksud corona virus merupakan suatu kelompok virus yang dapat menyebabkan penyakit pada hewan atau manusia. Beberapa 


\section{Vol. 1 No. 3 November 2021 e-ISSN : 2797-1031 | p-ISSN : 2797-0744}

jenis corona virus diketahui menyebabkan infeksi saluran nafas pada manusia mulai dari batuk pilek hingga yang lebih serius seperti Middle East Respiratory Syndrome (MERS) dan Severe Acute Respiratory Syndrome (SARS) (Schwartz, 2020). Awal mula penyakit yang disebabkan corona virus berasal pada Kota Wuhan, China pada akhir Desember 2019. Corona virus adalah virus yang beredar di antara hewan dengan beberapa di antaranya juga diketahui menginfeksi manusia. Kelelawar dianggap sebagai inang alami dari virus-virus ini, tetapi beberapa spesies hewan lain juga diketahui bertindak sebagai sumber. Sebagai contoh, Middle East Respiratory Syndrome Coronavirus (MERS-CoV) ditransmisikan ke manusia dari unta, dan Severe Acute Respiratory Syndrome Coronavirus-1 (SARS-CoV-1) ditransmisikan ke manusia dari kucing luwak. Informasi lebih lanjut tentang corona virus dapat ditemukan di lembar fakta $E C D C$, (Kemenkes RI, 2020).

Pada siklus I aktivitas siswa dalam pembelajaran sudah cukup memuaskan. Sebagian siswa cukup antusias dalam mengikuti pembelajaran, akan tetapi masih banyak juga yang belum memahami pembelajaran model kemandirian aktif. Pada siklus II aktivitas siswa pada pembelajaran mengalami peningkatan, siswa sudah mulai aktif dalam kelompoknya masingmasing. Setiap kelompok melakukan presentasi dengan baik. Pada siklus III aktivitas siswa pada pembelajaran mengalami peningkatan dari 2 siklus sebelumnya. Kemampuan siswa dalam melakukan presentasi dirasa semakin baik. Dengan penggunaan model kemandirian aktif dalam pembelajaran, aktivitas siswa dapat meningkat dan kognisi siswa dapat dilibatkan secara langsung.

Pada setiap awal pembelajaran di semua siklus, guru memberikan materi yang akan dibahas untuk mengembangkan pola pikir siswa. Kemudian guru membagi siswa menjadi beberapa kelompok terdiri dari 4 sampai 5 orang yang dipilih secara acak. Setelah itu guru memberikan tugas kelompok kepada masing-masing kelompok. Kemudian guru menunjuk salah satu kelompok untuk mempresentasikan hasilnya. Kelompok yang tidak melakukan presentasi berkewajiban mengisi lembar review dan aktif dalam diskusi. Dan pada akhirnya guru menyempurnakan jawaban dari kelompok yang melakukan presentasi. Lalu guru memberikan tugas mandiri yang dikerjakan secara perorangan. Di akhir pembelajaran guru mengulang lagi materi tersebut setelah itu guru mengadakan evaluasi (Arikunto, 2013).

Berdasarkan hasil dari siklus ke siklus diketahui bahwa penguasaan siswa terhadap materi fenomena kuantum menggunakan model pembelajaran aktif semakin meningkat. Materi fenomena kuantum berakhir tepat pada siklus III, sehingga siklus tindakan dihentikan.

Hal ini sejalan dengan pendapat para ahli yang mengatakan bahwa aktivitas merupakan prinsip yang sangat penting dalam proses pembelajaran. Aktivitas harus dilakukan oleh siswa sebagai usaha untuk meningkatkan hasil belajar. Pada prinsipnya belajar adalah berbuat untuk mengubah tingkah laku menjadimelakukan kegiatan. Tidak ada belajar kalau tidak ada aktivitas. Aktivitas siswa tidak hanya cukup dengan mendengarkan dan mencatat lazimnya terdapat di sekolah-sekolah tradisional. Aktivitas belajar itu adalah aktivitas yang bersifat fisik maupun mental. Dalam kegiatan belajar ke dua aktivitas itu harus selalu terkait. Sebagai contoh seseorang itu sedang belajar dengan membaca. Secara fisik kelihatan bahwa orang tadi membaca menghadapi suatu buku, tetapi mungkin pikiran dan sikap mentalnya tidak tertuju pada buku yang dibaca. Ini menunjukkan tidak ada keserasian antara aktivitas fisik dengan aktivitas mental (Nurhayati, 2017). Aktivitas fisik (kejiwaan/mental) harus saling terkait dalam kegiatan belajar. Jika tidak ada keserasian antara keduanya, maka belajar itu tidak akan optimal. Surakhmad menyatakan bahwa; Belajar semakin baik jika siswa diminta untuk melakukan halhal berikut; (1). Mengungkapkan informasi dengan bahasa mereka sendiri, (2). memberikan contoh-contoh, (3). mengenalnya dalam berbagai kondisi, (4). melihat hubungan antara satu gagasan dengan yang lain, (5). menggunakannya dengan berbagai cara, (6). memperkirakan beberapa konsekuensinya, (7). mengungkapkan lawan atau kebalikannya (Wulandari, 2016).

Sekolah adalah salah satu pusat kegiatan belajar, dengan demikian sekolah merupakan tempat untuk mengembangkan aktivitas. Diedrich membuat daftar kegiatan siswa yang antara lain; (1). Visual Activities, misalnya membaca, (2). Oral Activities, misalnya memberi 
pendapat, (3). Listening Activities, misalnya mendengarkan uraian, (4). Writing Activities, misalnya menulis laporan, (5). Drawing Activities, misalnya menggambar, (6). Motor Activities, misalnya melakukan percobaan, (7). Mental Activities, misalnya mengingat, (8). Emotional Activities, misalnya gugup.

Selain aktivitas yang sesuai dengan pembelajaran, terkadang di dalam kelas ada juga yang tidak sesuai dengan kegiatan pembelajaran (off task) seperti; (1). Berbicara yang tidak berhubungan dengan pelajaran, (2). Memandang ke kanan dan ke kiri, (3). Mengerjakan tugas lain, (4). Menggangu teman kelompok. (6). Tidak mendengarkan atau memperhatikan penjelasan guru. Jadi siswa dikatakan aktiif belahar jika dalam belajarnya siswa melaukan kegiatan yang sesuai pembelajaran. Dengan begitu siswa mampu memahami, mengingat dan mengaplikasikan materi yang telah disampaikan.

Penguasaan merupakan kemampuan menyerap arti dari materi suatu bahan yang dipelajari. Tetapi penguasaan bukan hanya sekedar mengingat mengenai apa yang telah dipelajari, tetapi melibatkan berbagai proses kegiatan mental sehingga bersifat dinamis. Fisika merupakan salah satu mata pelajaran yang didalamnya terdapat materi yang harus dikuasai. Apabila kita telah menguasai materi sebelumnya maka kita akan lebih mudah menguasai materi selanjutnya. Purwanto mengungkapkan; yang termasuk kategori kemampuan kognitif yaitu kemampuan untuk mengetahui, memahami, menerapkan, menganalisis, mensintesis dan mengevaluasi. Dan kemampuan tersebut sifatna hierarkis, artinya kemampuan pertama harus kitakuasai terlebih dahulu sebelum menguasaikemampuan yang seterusnya (Purwanto, 1996). Sementara itu Bahri mengungkapkan; Belajar pada hakikatnya adalah perubahan yang terjadi di dalam diri seseorang setelah berakhirnya melakukan aktivitas belajar. Dalam penelitian, fakta-fakta yang ada digambarkan oleh guru melalui kegiatan awal pembelajaran yakni dengan memberikan isu materi dan contohnya dalam kehidupan sehari-hari (Bahri, 2018). Menurut Egok; Fakta dipergunakan untuk mengidentifikasi suatu konsep, kemudian menggabungkan beberapa konsep untuk mengidentifikasi prinsip dan akhirnya prinsip diterapkan untuk memecahkan masalah. Bila siswa diajarkan fakta dan konsep, tentu tidak hanya berhenti sampai dengan prinsip, tetapi harus diadakan pula penerapan prinsip tersebut untuk apa. Apakah untuk mencari sebab-sebabnya, mengatasi masalah, meramalkan akibatnya, menganalisis suatu peristiwa dan sebagainya.Untuk mengetahui sejauh mana penguasaan materi dan keberhasilan siswa diperlukan tes yang dinyatakan dalam bentuk nilai tertentu. Penguasaan siswa terhadap suatu materi pelajaran sangat ditentukan oleh aktivitas belajar yang dilakukan oleh siswa itu sendiri (Egok, 2016).

Model kemandirian aktif merupakan sebuah model pembelajaran yang menerapkan pada pembelajaran yang dirancang berdasarkan sistem belajar mandiri dan belajar aktif yang dapat mengareahkan siswa untuk dapat belajar secara mandiri dan berpartisipasisecara aktif dalam kegiatan pembelajaran. Belajar mandiri akan membuat siswa menjadi lebih aktif, karena dalam belajar mandiri siswa diharuskan menyelesaikan tugas atau masalah yang ada melalui analisis, sintesis dan evaluasi suatu topik mata pelajaran secara mendalam, kadang-kadang juga melalui kombinasi antara pengetahuannya dengan pengetahuan yang diperoleh dari mata pelajaran lain. Siswa mendapatkan kepuasan belajar melalui tugas-tugas yang mampu diselesaikannya (Djamin, 1997). Melalui pendekatan belajar aktif, siswa diharapkan akan lebih mampu mengenal dan mengembangkan kapasitas belajar dan potensi yang dimilikinya. Belajar aktif juga dapat menuntut guru untuk bekerja secara profesional dan mengajar berdasarkan prinsip pembelajaran yang efektif dan efisien. Pembelajaran dengan model kemandirian aktif memperkenalkan cara pengelolaan kelas yang beragam. Kegiatan belajar klasikal tetap dipakai dengan tujuan guru dapat memberi penjelasan dan memperlihatkan materi secara jelas (Sani, 2019).

Aktivitas belajar yang kolaboratif dalam bentuk belajar kelompok dalam model pembelajaran ini akan mengarahkan siswa untuk belajar aktif. Seperti yang dikemukakan oleh Silberman, bahwa; aktivitas belajar kolaboratif membantu mengarahkan belajar aktif. Meskipun belajar independen dan kelas penuh instruksi juga mendorong belajar aktif, 


\section{Vol. 1 No. 3 November 2021 e-ISSN : 2797-1031 | p-ISSN : 2797-0744}

kemampuan untuk mengajar melalui aktivitas kerja kolaboratif dalam kelompok kecil akan memungkinkan guru mempromosikan belajar aktif dengan cara khusus (Silberman, 2002). Sedangkan menurut Suryabrata kerangka operasional model pembelajaran kemandirian aktif adalah sebagai berikut:

Tabel 10. Kerangka Operaional Model Pembelajaran

\begin{tabular}{lll}
\hline Kegiatan Guru & Langkah Pokok & Kegiatan Siswa \\
\hline Menyampaikan materi & Analisis materi & Melibatkan diri \\
\hline Memberi contoh & Peragaan & Merespon \\
\hline Memberi penugasan & Tafsir garap & Menafsir \\
\hline Mengevaluasi proses & Diskusi & Memberi argumen \\
\hline Memberi tugas kemandirian & Pendalaman & Latihan mandiri \\
\hline Mengevaluasi hasil & Penajaman fiksasi \& kreativitas & Mewujudkan kreativitas \\
\hline
\end{tabular}

Model kemandirian aktif merupakan sebuah model pembelajaram yamg diharapkan mampu memberdayakan siswa untuk berkembang secara maksimal. Efektifitas pembelajaran ditentukan oleh: (1). kemampuan siswa, (2). keterampilan pengajar, (3). jumlah waktu yang digunakan siswa untuk melakukajn tugas belajar, (4). model pembelajaran, dan (5). metode mengajar yang digunakan. Menurut Mayasari strategi yang digunakan untuk menapai tujuan meliputi yaitu; (1). Penajaman kognitif, (2). Instruksi verbal, (3). Demonstrasi, (5). Interpretasi, (6). Evaluasi, dan (7). Kreativitas. Belajar aktif memberi kesempatan siswa untuk berkembang secara optimal sesuai dengan kemampuannya. Dalam belajar aktif guru selain mengadakan kegiatan belajar yang bervariasi juga harus dapat memperhatikan perbedaan individu melalui peran aktif siswa dalam pembelajaran (Mayasari, 2019).

Dalam kegiatan belajar mengajar, setelah guru memberikan informasi dan melakukan demonstrasi, guru membagi siswa dalam kelompok yang terdiri dari 4-5 orang. Guru kemudian memberi penugasan dengan cara memberikan LKS kepada setiap kelompok dan setiap siswa dalam kelompok tertentu harus berdiskusi untuk menyelesaikan LKS tersebut bersama anggota kelompoknya. Setelah selesai masing-masing kelompok mempresentasikan hasil pekerjaannya, dan siswa dalam kelompok lain diberi kesempatan untuk bertanya. Dalam kegiatan ini siswa mencoba untuk merespon dan berargumentasi. Dengan cara ini semua kelompok akan merasa terpacu, sehingga dapat meningkatkan aktivitas belajar siswa, yang padfa akhirnya meningkatkan penguasaan siswa terhadap materi yang dipelajari. Kemudian setelah itu guru memberi pendalaman kepada siswa dengan memberikan tugas mandiri yang harus dikerjakan secara perorangan oleh masing-masing siswa.

Berdasarkan uraian teoritis dan pendapat dari para ahli yang telah diungkapkan, ternyata sejalan dengan hasil penelitian, bahwa penggunaan model kemandirian aktif dapat meningkatkan aktivitas belajar dan penguasaan fisika siswa pada materi fenomena kuantum siswa kelas XII MIPA-6 SMA Negeri 2 Bandar Lampung.

\section{KESIMPULAN}

Berasarkan hasil penelitian dan pembahasan, maka dapat disimpulkan bahwa tindakan pembelajaran yang dilakukan di kelas XII MIPA-6 pada SMA Negeri 2 Bandar Lampung menggunakan model kemandirian aktif yang paling optimal adalah; (1). Menyampaikan materi dengan cara memberikan isi materi dan mengungkapkan fakta terlebih dahulu sehingga dapat mengembangkan pola pikir siswa, (2). Memberikan contoh melalui peragaan dengan alat-alat peraga yang berhubungan dengan materi yang sedang dibahas, (3). Memberikan penugasan kepada siswa melalui tugas kelompok untuk melakukan kerja ilmiah dan membimbing siswa secara merata pasca saat melakukan kegiatan tersebut, (4). Mengevaluasi proses melalui diskusi siswa pada saat melakukan presentasi, (5). Memberikan pendalaman materi kepada siswa melalui tugas mandiri, dan (6). Mengevaluasi hasil dengan cara memberikan evaluasi akhir. Dengan pemberian tindakan seperti di atas pada setiap tahapan belajar maka diperoleh 


\section{Vol. 1 No. 3 November 2021 e-ISSN : 2797-1031 | p-ISSN : 2797-0744}

peningkatan aktivitas siswa dan penguasaan siswa dan penguasaan siswa terhadap materi dari tahapan ke tahapan selanjutnya, sebagai berikut; (1). Pada siklus I aktivitas siswa yang relevan dengan kegiatan pembelajaran sebesar $80,56 \%$ menjadi $86,11 \%$ pada siklus II atau naik $4,55 \%$, dan meningkat menjadi 90,41\% pada siklus III atau mengalami kenaikkan sebesar 4,30\%, (2). Penguasaan siswa terhadap materi fenomena kuantum pada siklus I sebesar 50,85 menjadi 68,96 pada siklus II atau naik $18,11 \%$ dan meningkat pada siklus III menjadi 80,84 atau mengalami kenaikkan sebesar $12,48 \%$.

Berdasarkan kesimpulan tersebut penulis mengajukan saran sebagai berikut; (1). Pada pembelajaran materi fenomena kuantum sebaiknya guru menggunakan pembelajaran dengan model kemandirian aktif, (2). Dalam pelaksanaan pembelajaran menggunakan model kemandirian aktif sebaiknya memperhatikan waktu yang diperlukan, (3). Guru memberikan bimbingan yang lebih merata pada saat pemberian tugas kelompok sehingga siswa termotivasi dalam melakukan kegiatan pembelajaran, (4). Guru memberikan penjelasan yang lebih lengkap kepada siswa tentang materi yang sedang dibahas, (5). Guru memberikan motivasi kepada siswa sehingga siswa lebih berminat dalam kegiatan pembelajaran.

\section{DAFTAR PUSTAKA}

Arikunto, Suharsimi. (2013). Dasar-Dasar Evaluasi Pendidikan. Jakarta: Bumi Aksara.

Bahri, Prisha S., \& Zaenuri, \& Sukestiyarno, Y. (2018). Problem Solving Ability on Independent Learning and Problem Based Learning with Based Modules Ethnomatematics Nuance. Unnes Journal of Mathematics Education Research, 7(2), 218-224.

Djamin, Syaiful Bahri dan Aswan Zain. (1997). Strategi Belajar Mengajar. Jakarta: Rineka Cipta.

Education, World Bank Group. 2020. Educational Policies In The Covid-19 Pandemic: What Can Brazil Learn From The Rest of The World?.

Egok, Asep Sukenda. (2016). Kemampuan Berpikir Kritis dan Kemandirian Belajar dengan Hasil Belajar Matematika. Journal of Chemical Information and Modeling, 53(9), 1689-1699. ]

Kamus Besar Bahasa Indonesia (KBBI). (2020). https://kbbi.kemdikbud.go.id/entri/pandemi 23 April 2020.

Kesehatan Republik Indonesia, Kementrian. (2020) Situasi https://www.kemkes.go.id/. 7 April 2020.

Mayasari, T. R. (2019). Pengaruh Kemandirian Belajar terhadap Kemampuan Pemecahan Masalah Matematis Siswa SMP. Jurnal Cendekia: Jurnal Pendidikan Matematika, 3(1), 82-88.

Nadzhiroh, Faridatun. (2017). Analisa Efektifitas Sistem Pembelajaran Berbasis "E-Learning", Jurnal Ilmu Komputer dan Desain Komunikasi Visual (Jikdiskomvis). Vol 2, 2017.

Nasution, S. (1992). Teknologi Pendidikan. Bandung: Jemars.

Nurhayati, E. (2017). Penerapan "Scaffolding" untuk Pencapaian Kemandirian Belajar Siswa. Jurnal Penelitian Pendidikan dan Pengajaran Matematika, 3(1), 21-26.

Purwanto, Ngalim. (1996). Psikologi Pendidikan. Bandung: Remaja Rosdakarya.

Roestiyah, N.K.. (1986). Masalah-masalah Ilmu Keguruan. Jakarta: Bina Aksara..

Roestiyah, N.K., (1988). Strategi Belajar Mengajar. Jakarta: Bina Aksara.

Saefullah, A. Dan Siahaan, P. I. M. S. (2013). Hubungan Antara Sikap Kemandirian Belajar Dan Prestasi Belajar Siswa Kelas X Pada Pembelajaran Fisika Berbasis Portofolio. Journal WaPFi (Wahana Pendidikan Fisika), 1(1), 26-36.

Sani, Ridwan Abdullah. (2019). Strategi Belajar Mengajar. Depok : PT. Raja Grafindo Persada.

Schwartz, Andrew M, dkk. (2020). Managing Resident Workforce and Education During the COVID-19 Pandemic Evolving Strategies and Lessons Learned. Journal of Bone and Joint Surgery.

Sudjana. (1992). Metode Statistika. Bandung: Tarsito. 
Vol. 1 No. 3 November 2021 e-ISSN : 2797-1031 | p-ISSN : 2797-0744

Wulandari, S.P. (2016). Menciptakan Kemandirian Belajar Siswa Melalui Pembelajaran Berbasis "Discovery Learning” dengan "Assessment for Learning”. Journal PRISMA, Prosiding Seminar Nasional Matematika, 226-232. 